\title{
Degradation of hemicellulose and pectin by horse caecum contents
}

\author{
BY A. BONHOMME-FLORENTIN*
}

L.A. CNRS $n^{\circ} 138$, Groupe de Zoologie et Protistologie, les Cézeaux, BP 45, 63170

Aubiere, and Laboratoire de Zoologie, U.F.R. Sciences, BP 347, 51062 Reims-Cédex, France

(Received 13 October 1987 - Accepted 15 March 1988)

\begin{abstract}
1. Polysaccharide depolymerases and glycoside hydrolases involved in the breakdown of plant structural polysaccharides (hemicellulose and pectins) were monitored in three fractions of the liquid phase of horse caecum digesta : acellular fluid (AF), bacteria (B) and protozoa plus bacteria (PB).

2. Both bacteria and protozoa were found to be involved in the decomposition of pectic substances, with two enzymic activities: depolymerase (polygalacturonase, EC 3.2.1.15; and pectin lyase, EC 4.2.2.10) and esterase (pectinesterase, EC 3.1.1.11). The activity of the PB fraction was higher than that of B.

3. With hemicellulosic substrates, all three fractions showed a significant xylan endo-1,3- $\beta$-xylosidase ( $E C$ 3.2 .1 .32 ) activity. Mannan was hardly broken down.

4. Galactomannan and arabinogalactan were broken down more extensively by the PB fraction than by the B fraction. Glycosidase activities (xylan 1,4- $\beta$-xylosidase, EC 3.2.1 .37 and $\alpha$-L-arabinofuranosidase, EC 3.2.1 .55) were also observed.
\end{abstract}

Forage contains various carbohydrate polymers which are the main source of energy for herbivores. The digestion of cellulose and fibrous plant material depends on the ability of endosymbiotic micro-organisms to break down the walls of plant cells and to ferment the carbohydrates. Like the population of the rumen, protozoa and bacteria in the caecum colonize the plant fragments to which they are attached (Bonhomme-Florentin, 1985).

A network of enzymes is needed to hydrolyse these substrates. A study has been made of the distribution of pectinolytic enzymes (polygalacturonase, EC 3.2.1.15; pectin lyase, $E C$ 4.2.2.10; pectinesterase, EC 3.1.1.11) and hemicellulase enzymes (xylan endo-1,3- $\beta$ xylosidase, $E C 3.2 .1 .32 ; \beta$-mannosidase, $E C 3.2 .1 .25$ ), in three fractions of the caecum contents: acellular fluid (AF), bacteria (B), and protozoa plus bacteria (PB).

\section{MATERIALS AND METHODS}

Samples of caecum contents were collected from six slaughtered horses. Each sample was used to prepare three fractions (AF, B and $\mathrm{PB}$ ) by the procedure summarized in Fig. 1. The fractions were then examined for enzyme activity as follows.

\section{Incubations}

Polygalacturonase. Two incubation media were used. One consisted of $0.25 \mathrm{ml}$ polygalacturonic acid solution $(10 \mathrm{~g} / 1 ; \mathrm{pH}$ adjusted to the desired value with $0.5 \mathrm{M}$-sodium hydroxide), $0.5 \mathrm{ml} 20 \mathrm{~mm}-N$-tris-(hydroxymethyl) methyl-2-aminoethanesulphonic acid (TES; pH $6.0,7.0$ or 8.0 ), and $0.25 \mathrm{ml}$ enzymic extract (PB, B or AF). Two controls were used: (1) $0.25 \mathrm{ml}$ polygalacturonic acid solution $(10 \mathrm{~g} / \mathrm{l})$ with $0.75 \mathrm{ml}$ TES buffer, (2) $0.25 \mathrm{ml}$ enzymic extract with $0.75 \mathrm{ml}$ TES. The other medium consisted of $1 \mathrm{ml}$ enzymic extract added to a pectin solution $(10 \mathrm{~g} / 1)$ in a phosphate-citrate buffer $(\mathrm{pH} 7.0,15 \mathrm{ml})$ (MacIlvaine, 1921). Incubation was carried out at $40^{\circ}$.

* Present address: Laboratoire de Parasitologie, Hôpital Maison Blanche, 45 rue Cognacq Jay, 51092 Reims-Cédex, France. 


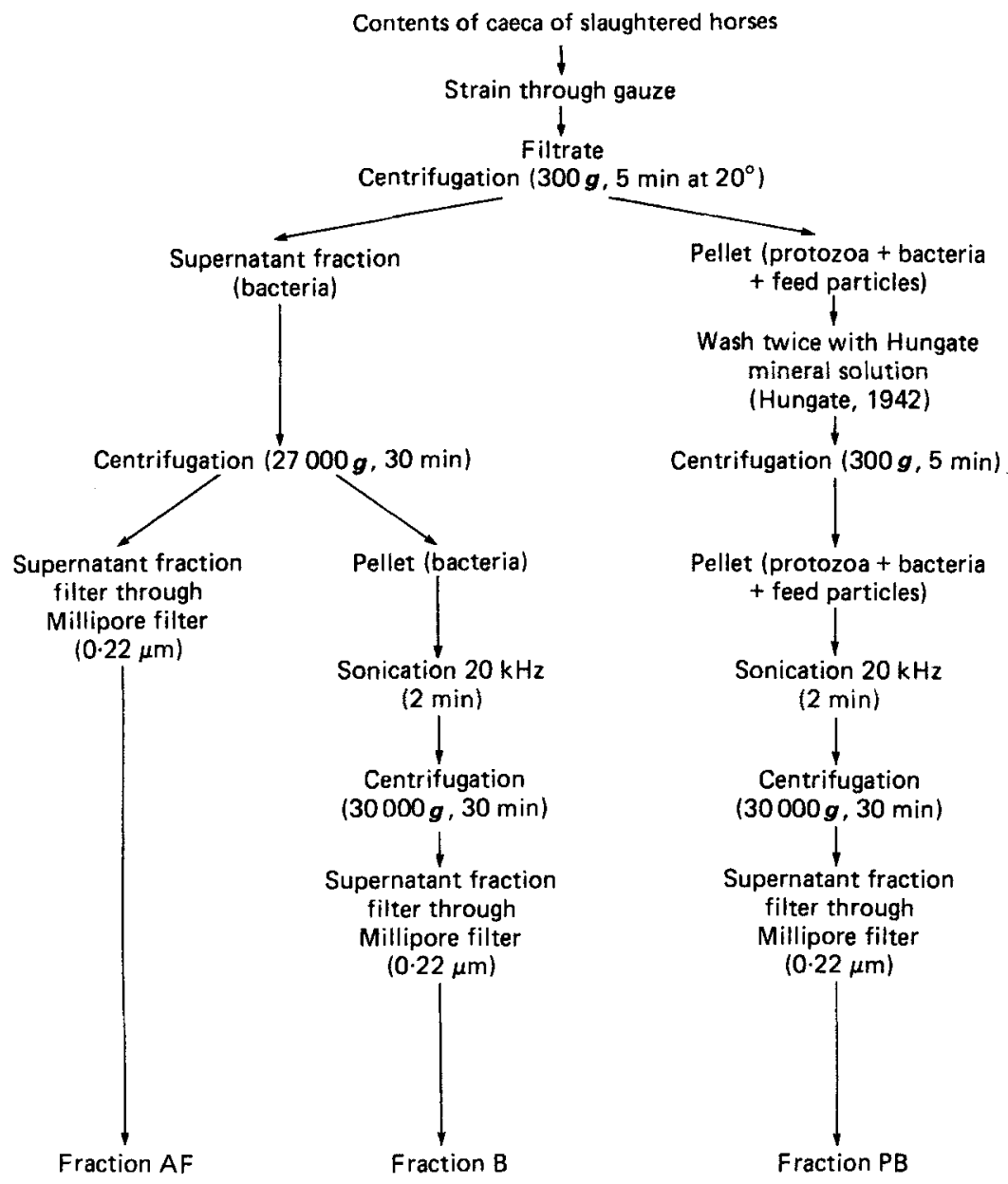

Fig. 1. Fractionation of horse caecum contents into acellular fluid (AF), bacteria (B) and protozoa plus bacteria (PB).

Pectin lyase. A pectin solution $(20 \mathrm{~g} / 1)$ in distilled water was centrifuged at $34000 \mathrm{~g}$ for $1 \mathrm{~h}$ to separate out the colloidal particles. Phosphate-citrate buffer solutions (3 vol.) of various $\mathrm{pH}$ values ranging from 4.0 to 8.0 were added to the supernatant fractions ( 1 vol.). This substrate solution $(2 \mathrm{ml})$ and the enzymic extract $(0 \cdot 1 \mathrm{ml}$ diluted $1: 3, \mathrm{v} / \mathrm{v})$ were incubated at $40^{\circ}$.

Pectinesterase. The incubation medium consisted of $1 \mathrm{ml}$ of the substrate (a pectin solution $(20 \mathrm{~g} / \mathrm{l})$ in phosphate citrate buffers with $\mathrm{pH}$ values of $5 \cdot 0,6.0$ and $7 \cdot 0)$ and $0.25 \mathrm{ml}$ enzymic extract. Incubation was carried out at $40^{\circ}$ for $18 \mathrm{~h}$.

Hemicellulases. The incubation medium comprised $0.2 \mathrm{ml}$ hemicellulose solution $(10 \mathrm{~g} /$ 1) and $0.5 \mathrm{ml}$ enzymic extract buffered with $0.5 \mathrm{ml}$ citrate buffer solution $(0.1 \mathrm{M}), \mathrm{pH} 5.0$ and 6.0 , or TES buffer $(20 \mathrm{~mm}), \mathrm{pH} 7.0$ and 8.0 . The hemicelluloses used were obtained from Sigma Chemical Co., Poole, Dorset. They were xylan (from oat spelts) dissolved in $0.5 \mathrm{M}-$ sodium hydroxide and adjusted to the desired $\mathrm{pH}$ value with $1 \mathrm{M}$-hydrochloric acid, mannan (from Saccharomyces cerevisiae), arabinogalactan (from larchwood) or galactomannan (guar gum). Incubation was carried out at $40^{\circ}$ for 0.5 and $5 \mathrm{~h}$. 
Glycosidases. The incubation media consisted of $0.2 \mathrm{ml} p$-nitrophenyl derivative, $\beta$-Dxylopyranoside $(3 \mathrm{mg} / \mathrm{ml}$ water), $\beta$-D-mannopyranoside $(3 \mathrm{mg} / 4 \mathrm{ml}$ water) or $\alpha$-Larabinofuranoside $(3 \mathrm{mg} / 4 \mathrm{ml}$ water), together with $0.7 \mathrm{ml} 200 \mathrm{~mm}$-phosphate buffer, pH 7.0, or $100 \mathrm{~mm}$-citrate buffer, $\mathrm{pH} 5.0$ and 6.0 , and $0.1 \mathrm{ml}$ enzymic extract (diluted $1: 3$, $\mathrm{v} / \mathrm{v}$ ). Incubation was carried out at $40^{\circ}$ for $2 \mathrm{~h}$. In all incubations, controls were included, where either the substrate or the enzymic extract were omitted.

\section{Analytical procedures}

Viscosity. The variation in viscosity of the pectin $(10 \mathrm{~g} / 1)$ solution in the second incubation medium (see p. 185) was measured by means of an Ostwald viscometer. The intrinsic viscosity $\left(\eta_{i}\right)$ was estimated with the Hess \& Philipoff (1937) formula:

$$
\eta_{\mathrm{i}}=8\left(\eta_{\mathrm{r}}^{\frac{1}{8}}-1\right) / C_{\mathrm{s}}
$$

where $\eta_{\mathrm{r}}$ is the relative viscosity and $C_{\mathrm{s}}$ is the concentration of substrate $(\mathrm{g} / \mathrm{l})$.

Reducing sugar. The reducing sugar produced was measured according to the Nelson (1944) microcuprimetric method as galacturonic acid for determining polygalacturonase activity, and as xylose, mannose and galactose for determining hemicellulase activity.

Measure of absorbance. For determining pectin lyase activity, the absorbance was measured at $235 \mathrm{~nm}$ at time zero $\left(t_{0}\right)$ and after various periods of incubation. One unit of activity is defined as an increase in optical density of 0.1 at $235 \mathrm{~nm}$ in $2 \mathrm{~h}$ expressed per $\mathrm{ml}$ enzymic extract. Specific activity is expressed on a per $\mathrm{mg}$ protein basis.

Gas-liquid chromatography and thin-layer chromatography. The pectinesterase activity was determined by gas-liquid chromatography as methanol produced by the breakdown of pectin in a $20 \mathrm{~g} / 1$ solution. After the incubation period, butan-2-ol $(0.3 \mu \mathrm{l})$ was added to the incubation medium as an internal standard. Then, ammonium sulphate $(3.6 \mathrm{M})$ and sodium dihydrogen phosphate $(1 \mathrm{M})$ were added, and the mixture was left overnight at $4^{\circ}$. The methanol released was measured in a gas-liquid chromatograph (Intersmat IGC $121 \mathrm{FL}$ ) with a stainless-steel column ( $2 \mathrm{~m}$ in length, $3.18 \mathrm{~mm}$ in diameter) and a Porapak $\mathrm{Q}$ phase (100-120 mesh). The settings were as follows: oven $180^{\circ}$, injector $200^{\circ}$, detector $220^{\circ}$. The carrier gas was nitrogen at a pressure of 1 bar.

For determining polygalacturonase activity, after $6 \mathrm{~h}$ incubation, the breakdown of polygalacturonic acid was determined by ascending chromatography on silica gel (F1500, Merck). Two solvents were used: (1) acetic acid-pyridine ethyl acetate water (1:5:5:3, by vol.), and (2) butanol-acetic acid-water (4:3:3, by vol.). Ammoniacal silver nitrate (Trevelyan et al. 1950) and $p$-anisidine were used as localizing reagents.

For determining hemicellulase activity, after $6 \mathrm{~h}$ incubation, the breakdown of xylan or mannan was evaluated by ascending chromatography on silica gel (F1500). There were two runs in the solvent (butanol-pyridine-water $6: 4: 3$, by vol.). The localizing reagents used were $p$-anisidine for mannose and aniline phtalate for xylose.

Colorimetric methods. For determining glycosidase activities with nitrophenyl derivatives as substrates, the released $p$-nitrophenol was determined (after the reaction had been stopped by the addition of $2 \mathrm{ml} 0.2 \mathrm{M}$-sodium borate buffer, $\mathrm{pH} \mathrm{9.8)} \mathrm{from} \mathrm{a} \mathrm{standard} \mathrm{range}$ of $p$-nitrophenol in buffer solution from 10 to $100 \mu \mathrm{M}$. The absorbance was measured at $400 \mathrm{~nm}$. The results are expressed as $\mu \mathrm{mol} p$-nitrophenol $/ \mathrm{h}$ per $\mathrm{mg}$ protein. Protein in each fraction ( $\mathrm{PB}, \mathrm{B}$ and $\mathrm{AF}$ ) was determined according to the method of Lowry et al. (1951).

\section{RESULTS}

Samples from different horses showed variations in flora and fauna. Results given in the tables and described in the following sections are for single samples, but although absolute 
Table 1. Polygalacturonase (EC 3.2.1.15) activity of fractions of horse caecum contents

\begin{tabular}{ccccc}
\hline & \multicolumn{3}{c}{$\begin{array}{c}\text { nmol Galacturonic acid } / \mathrm{min} \\
\text { per mg protein }\end{array}$} \\
$\begin{array}{c}\text { Fraction* incubated with } \\
\text { polygalacturonic acid }\end{array}$ & pH 6.0 & $\mathrm{pH} 7 \cdot 0$ & $\mathrm{pH} 8.0$ \\
\hline AF & 21 & 26 & $30 \cdot 7$ \\
B & 21 & 18.3 & 27.5 \\
PB $\dagger$ & 157 & 237.6 & 256 \\
\hline
\end{tabular}

AF, acellular fluid; B, bacteria; $\mathrm{PB}$, protozoa plus bacteria.

* Protein values of fractions ( $\mu \mathrm{g} / \mathrm{ml}$ incubation medium using bovine albumin as standard): AF 480, B 240, PB 275; for details of fractions, see Fig. 1.

$\dagger$ Cycloposthium, $9 \times 10^{4} / \mathrm{ml}$.

Table 2. Changes in the intrinsic viscosity $\left(\eta_{i}\right)$ of a pectin solution $(10 \mathrm{~g} / l)$ incubated with fractions of horse caecum contents*

\begin{tabular}{ccccccc}
\hline \hline & \multicolumn{7}{c}{$\eta_{1}$} \\
\cline { 2 - 7 } Incubation period (min) & $\mathrm{PB}_{\mathbf{1}} \dagger$ & $\mathbf{P B}_{2} \dagger$ & $\mathrm{B}_{1}$ & $\mathrm{~B}_{2}$ & $\mathrm{AF}_{1}$ & $\mathrm{AF}_{2}$ \\
\hline 0.5 & 0.269 & 0.272 & 0.243 & 0.259 & 0.237 & 0.233 \\
5 & 0.263 & 0.262 & 0.240 & 0.253 & 0.233 & 0.229 \\
10 & 0.253 & 0.253 & 0.237 & 0.251 & 0.231 & 0.227 \\
15 & 0.248 & 0.225 & 0.235 & 0.245 & 0.225 & -2 \\
30 & 0.242 & 0.167 & 0.225 & 0.240 & 0.222 & 0.226 \\
40 & 0.238 & 0.146 & 0.225 & 0.238 & 0.218 & 0.226 \\
\hline
\end{tabular}

$\mathrm{AF}_{1}, \mathrm{AF}_{2}$, acellular fluid; $\mathrm{B}_{1}, \mathrm{~B}_{2}$, bacteria; $\mathrm{PB}_{1} \mathrm{~PB}_{2}$, protozoa plus bacteria.

* Protein values of the fractions $\left(\mu \mathrm{g} / \mathrm{ml}\right.$ incubation medium using bovine albumin as standard) $\mathrm{PB}_{1} 195$, $\mathrm{PB}_{2} 375, \mathrm{~B}_{1} 390, \mathrm{~B}_{2} 280, \mathrm{AF}_{1} 260, \mathrm{AF}_{2} 250$.

$\dagger$ Ciliate composition of PB fractions: $\mathrm{PB}_{1}$ Blepharocorys $1.6 \times 10^{6} / \mathrm{ml} ;$ Cycloposthium $6.2 \times 10^{4} / \mathrm{ml}^{2} \mathrm{~PB}_{2}$ Cycloposthium $3.4 \times 10^{5} / \mathrm{ml}$; Didesmis, Blepharocorys, Paraisotricha.

values varied between samples, the patterns of relations between the fractions $\mathrm{PB}, \mathrm{B}$ and AF obtained from different caecum contents were consistent.

\section{Pectinolytic activity of the fractions}

Three enzymic pathways for degradation of pectin were observed. Two were depolymerase activities, the first causing hydrolysis of $1 \rightarrow 4$ glycosidic linkages (polygalacturonase) and the second resulting in the $\beta$ elimination from the esterified carboxy group to give unsaturated uronides (pectin lyase). The third is a saponifying enzymic activity which hydrolyses the methoxyl groups from the pectin (pectinesterase). The results of the breakdown of polygalacturonic acid to galacturonic acid are shown in Tables 1 and 2. This activity was found mainly in the $P B$ fraction, as indicated by the amount of reducing sugars determined as galacturonic acid. The activities per $\mathrm{mg}$ protein in fractions B and AF were comparable, but the latter contained twice as much protein. In the four different samples of caecum contents examined, the decrease in the intrinsic viscosity of a pectin solution $(10 \mathrm{~g} / \mathrm{l})$ was two to six times more in fraction PB than in fraction $\mathrm{B}$. The decrease was four times as great when the $\mathrm{PB}$ fraction was composed mainly of Cycloposthium spp. $\left(\mathrm{PB}_{2}\right)$ than 
Table 3. Chromatographic results of the degradation of polygalacturonic acid by the fractions of horse caecum contents

\begin{tabular}{|c|c|c|c|c|c|}
\hline \multirow{2}{*}{$\begin{array}{l}\text { Solvent*... } \\
\text { Fraction }\end{array}$} & \multicolumn{2}{|c|}{1} & \multicolumn{2}{|c|}{2} & \multirow[b]{2}{*}{ Identification } \\
\hline & $R_{\mathrm{f}}$ & $R_{\mathrm{G}}$ & $R_{\mathrm{f}}$ & $R_{\mathrm{G}}$ & \\
\hline \multirow[t]{2}{*}{$\mathrm{AF}+\mathrm{PG}$} & 0.23 & $0 \cdot 25$ & - & - & TG \\
\hline & 0.68 & 0.76 & $\ldots$ & - & - \\
\hline \multirow[t]{4}{*}{$\mathrm{B}+\mathrm{PG}$} & 0.23 & $0 \cdot 25$ & 0.22 & 0.44 & $\mathrm{TG}$ \\
\hline & & & $0 \cdot 34$ & 0.67 & $\mathrm{DG}$ \\
\hline & & & 0.49 & 0.95 & MG \\
\hline & & & 0.62 & $1 \cdot 2$ & Galactose \\
\hline \multirow[t]{4}{*}{$\mathrm{PB}+\mathrm{PG}$} & $0 \cdot 23$ & $0 \cdot 25$ & $0 \cdot 22$ & 0.44 & TG \\
\hline & 0.50 & 0.56 & $0-34$ & 0.67 & $\dot{D} G$ \\
\hline & 0.77 & 0.85 & 0.5 & 0.97 & MG \\
\hline & & & 0.58 & $1 \cdot 12$ & Galactose \\
\hline MG & 0.9 & 1 & 0.51 & 1 & - \\
\hline Galactose & - & - & 0.56 & $1 \cdot 1$ & - \\
\hline
\end{tabular}

$R_{\mathrm{f}}=X / S ; R_{\mathrm{G}}=X / G$, where the distance travelled by the substance (TG, DG, MG, galactose) is $X$, by the galacturonic acid is $G$ and by the solvent front is $S$.

PG, polygalacturonic acid; $M G$, galacturonic acid; DG, digalacturonic acid; TG, trigalacturonic acid.

* Solvent 1 , acetic acid-pyridine-ethyl-acetate-water $(1: 5: 5: 3$, by vol.), location reagent ammoniacal silver nitrate; solvent 2 , butanol-acetic acid-water $(4: 3: 3$, by vol.), location reagent $p$-anisidine.

Table 4. Specific pectin lyase (EC 4.2.2.10) activity* of fractions of horse caecum contents $\dagger$

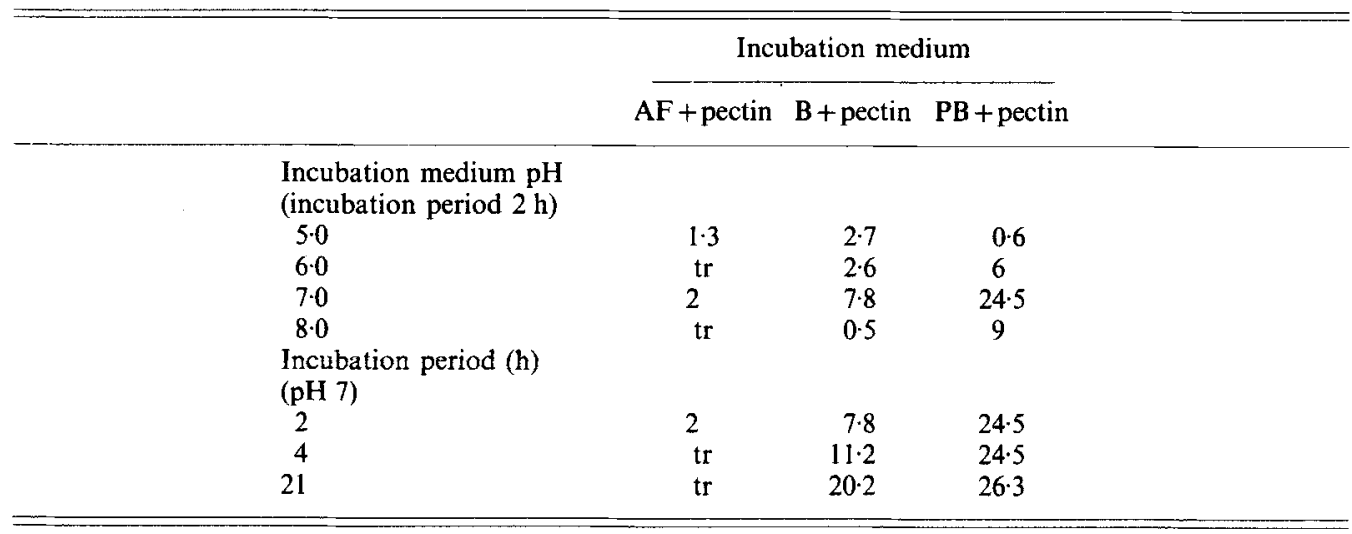

tr, trace amounts; AF, acellular fluid; B, bacteria; PB, protozoa plus bacteria.

* One unit of activity is defined as the increase in optical density of 0.1 at $235 \mathrm{~nm}$ in $2 \mathrm{~h}$ expressed per ml enzymic extract, specific activity is expressed in units per mg protein.

$\dagger$ Protein values of the fractions (mg/ml incubation medium using bovine albumin as standard): AF I.4, B 2, PB 1; for details of fractions, see Fig. 1.

when it also contained large numbers of Blepharocorys spp. $\left(\mathrm{PB}_{1}\right)$ (Table 2). These results are put forward as an example of viscosity variations induced by fractions from different caecum contents. They show that pectinolytic activity is dependent on the qualitative composition of caecum microfauna. Chromatographic analysis indicated that polygalacturonic acid was broken down into tri-, di- and monogalacturonic acids by fractions 
Table 5. Pectinesterase (EC 3.1.I.II) activity of fractions of horse caecum contents* (nmol methanol/h)

\begin{tabular}{lrrr}
\hline pH of incubation medium ... & 5.0 & 6.0 & $7 \cdot 0$ \\
\hline AF + pectin & 7.8 & $8 \cdot 1$ & 7.5 \\
B + pectin & 60.3 & $50 \cdot 6$ & $20 \cdot 3$ \\
PB + pectin & 41.5 & $317 \cdot 2$ & $23 \cdot 4$ \\
\hline
\end{tabular}

AF, acellular fluid; B, bacteria ; PB, protozoa plus bacteria.

* Protein values of fractions ( $\mathrm{mg} / \mathrm{ml}$ incubation medium using bovine albumin as standard): AF 0.8, B 0.9, PB $1 \cdot 2$.

Table 6. Hemicellulase activity of fractions of horse caecum contents*

\begin{tabular}{|c|c|c|c|c|c|}
\hline \multirow[b]{2}{*}{ Fraction } & \multirow[b]{2}{*}{ Substrate } & \multicolumn{4}{|c|}{ nmol sugar produced/h per mg protein } \\
\hline & & $\mathrm{pH} \mathrm{5 \cdot 0}$ & $\mathrm{pH} 6.0$ & $\mathrm{pH} 7.0$ & $\mathrm{pH} 8 \cdot 0$ \\
\hline $\begin{array}{l}\text { AF } \\
\text { B } \\
\text { PB }\end{array}$ & $\mathrm{X}$ & $\begin{array}{l}1190 \\
1314 \\
2210\end{array}$ & $\begin{array}{l}1445 \\
1134 \\
2100\end{array}$ & $\begin{array}{r}1710 \\
540 \\
1300\end{array}$ & $\begin{array}{l}511 \\
318 \\
900\end{array}$ \\
\hline $\begin{array}{l}\text { AF } \\
\text { B } \\
\text { PB }\end{array}$ & $\mathbf{M}$ & $\begin{array}{c}390 \\
120 \\
\operatorname{tr}\end{array}$ & $\begin{array}{c}462 \\
\mathrm{tr} \\
\mathrm{tr}\end{array}$ & $\begin{array}{c}354 \\
\operatorname{tr} \\
540\end{array}$ & $\begin{array}{r}390 \\
\mathrm{tr} \\
540\end{array}$ \\
\hline $\begin{array}{l}\text { AF } \\
\text { B } \\
\text { PB }\end{array}$ & GM & $\begin{array}{c}49 \\
90 \cdot 7 \\
311 \cdot 5\end{array}$ & $\begin{array}{r}21 \\
63 \\
295\end{array}$ & $\begin{array}{c}\operatorname{tr} \\
31.6 \\
177.6\end{array}$ & $\begin{array}{c}\operatorname{tr} \\
49 \cdot 4 \\
122\end{array}$ \\
\hline $\begin{array}{l}\text { AF } \\
\text { B } \\
\text { PB }\end{array}$ & AG & $\begin{array}{c}84 \\
55 \cdot 5 \\
110\end{array}$ & $\begin{array}{l}84 \\
51 \cdot 3 \\
104\end{array}$ & $\begin{array}{l}21 \\
\operatorname{tr} \\
54 \cdot 6\end{array}$ & $\begin{array}{c}21 \\
t r \\
68.3\end{array}$ \\
\hline
\end{tabular}

tr, trace amounts; AF, acellular fluid; B, bacteria; PB, protozoa plus bacteria; X, xylan; M, mannan; GM, galactomannan; $\mathrm{AG}$, arabinogalactan.

* Protein values of the fractions $(\mathrm{mg} / \mathrm{ml}$ of incubation medium using bovine albumin as standard): AF, 0.6, B 1.2, PB 2 and 1.6 (with GM and AG respectively); for details of fractions, see Fig. 1 .

Table 7. Glycosidase activity of fractions of horse caecum contents* on two p-nitrophenyl derivatives (umol $\mathrm{p}$-nitrophenol/h per $m g$ protein)

\begin{tabular}{lccccc}
\hline pH of incubation medium ... & $5 \cdot 0$ & 6.0 & 7.0 & 8.0 \\
B + NX & 26.7 & 6.7 & $\operatorname{tr}$ & $\operatorname{tr}$ \\
PB+NX & 177.5 & 1100 & 537.5 & $\operatorname{tr}$ \\
B + NA & 23 & 227 & 143 & 60 \\
PB-NA & 135 & 792.5 & 647.5 & 280 \\
\hline
\end{tabular}

tr, trace amounts; B, bacteria ; PB, protozoa plus bacteria; NX, $p$-nitrophenyl $\beta$-D-xylopyranoside; NA, $p$ nitrophenyl $\alpha$-L-arabinofuranoside.

* Protein values of the fractions $(\mu \mathrm{g} / \mathrm{ml}$ of incubation medium using bovine albumin as standard): B 150, PB 200 ; for details of fractions, see Fig. 1 . 
PB and B. With fraction AF, only a small amount of trigalacturonic acid was detected (Table 3).

The depolymerizing activity (pectin lyase) was concentrated in fractions B and PB (Table 4). Pectin lyase activity of fraction $B$ was particularly evident after $20 \mathrm{~h}$ of incubation. The $\mathrm{PB}$ fraction reached its peak of activity after $2 \mathrm{~h}$ of incubation. The optimum $\mathrm{pH}$ was 7.0 . The AF fraction had no pectin lyase activity. The de-esterification of pectin (by pectinesterase), with the production of free carboxyl groups and methanol was greatest in fraction PB. At the optimum $\mathrm{pH}$ of 6.0 , the pectinesterase activity of fraction PB was higher than that of fraction B. Fraction AF had very weak activity (Table 5).

\section{Hemicellulase activity of the fractions.}

As regards the various hemicellulase activities, all three fractions contained significant xylan endo-1,3- $\beta$-xylosidase activity. Chromatrographic analysis indicated the breakdown of xylan into xylose. With fraction $B$, no chromatographic spots were observed which could be xylodextrins, xylotriose or xylobiose. Galactomannan was only partially broken down into mannose and galactose by all three fractions in a $\mathrm{pH}$ range between 5.0 and 6.0 ; fraction PB had the highest activity. Arabinogalactan was broken down into arabinose and galactose by all three fractions in the same $\mathrm{pH}$ zone. Fraction $\mathrm{PB}$ contained twice the activity of fraction $\mathrm{B}$ (Table 6). As regards glycosidase activities, xylan 1,4- $\beta$-xylosidase and $\alpha$-L-arabinofuranosidase were observed in fractions $\mathrm{PB}$ and $\mathrm{B}$ on the nitrophenyl derivatives $\beta$-D-xylopyranoside and $\alpha$-L-arabinofuranoside (Table 7). The optimum $\mathrm{pH}$ of these activities was 6.0 for fraction PB. Fraction AF showed no activity. The $p$-nitrophenyl $\beta$-mannopyranoside was partially broken down. Fractions PB and B released $10 \mu \mathrm{mol} p$ nitrophenol/h per $\mathrm{mg}$ protein at $\mathrm{pH} 5 \cdot 0$.

\section{DISCUSSION}

According to Hintz (1969), horses digest fibre only two-thirds as efficiently as ruminants do. Observing faecal particles under the electron microscope, Grenet et al. (1984) also reported that horses digest plant cell walls less well. Harbers et al. (1981), who studied the digestion of three types of forage by horses, found that the hemicelluloses of hay from Andropogon gerardi, Festuca arundinacea and Bromus inermis have apparent digestibility coefficients of $0.542,0.577$ and 0.668 respectively. Peltonen et al. (1978) observed that the microbial population and its activity in the digestive tract are particularly influenced by the physicochemical composition of the forage. As in the rumen, the endosymbiotic micro-population of the caecum and colon decomposes cell-wall carbohydrates (hemicellulose and pectin). These polysaccharides are broken down through an interaction of depolymerases and glycosidases; these latter isolate the side chains of the main chain and hydrolyse the fragments of oligosaccharides released by the activity of the depolymerases. Pectin, the polymer of galacturonic acid which represents a small proportion of the cell-wall carbohydrates in forage, is broken down in the rumen by most of the ciliates (Isotricha, Spirotricha, Ophryoscolex, Epidinium and Polyplastron spp.) (Abou Akkada \& Howard, 1961; Abou Akkada et al. 1963; Wright, 1960, 1961; Mah \& Hungate, 1965), with the release of oligouronides, galacturonic acid and methanol. Similarly in the caecum, the ciliates, mainly Cycloposthium spp. but also Blepharocorys spp., actively degrade pectic substances by means of three enzymes: polygalacturonase, pectin lyase and pectinesterase. The bacterial fraction is linked to this activity in the same way as in the rumen, where there is synergy between bacteria hydrolysing the pectic substances and those using the endproducts of this hydrolysis (Prins, 1977). The hemicelluloses in forage, which represent $30-40 \%$ of the polysaccharide complex, are mainly $\beta-1,4-x y l a n s$. In ruminants, bacteria 
(Dehority, 1965, 1973) and entodiniomorph ciliates (Ophryoscolex, Epidinium and Polyplastron) (Bailey et al. 1962; Abou Akkada et al. 1963; Abou Akkada \& El Shazly, 1965; Clarke, 1977) participate in the hydrolysis of xylan, arabinan and mannan. The distribution of enzymes which degrade cell-wall polysaccharides in the caecum, shows that the protozoal fraction degrades cellulose (Bonhomme-Florentin, 1974) and hemicelluloses, and has glycosidases linked to the depolymerization of these structural constituents. The cellulose is broken down by one cellulase $(E C$ 3.2.1.4) and one $\beta$-D-glucosidase ( $E C$ 3.2.1.21) into glucose. The hemicelluloses are hydrolysed into xylose, arabinose, and galactose by glycanhydrolases (xylan endo-1,3- $\beta$-xylosidase, EC 3.2.1.32; $\alpha$-L-arabinanase), by glycosidases (xylan $1,4-\beta$-xylosidase, $E C \quad 3.2 .1 .37 ; \alpha$-L-arabinofuranosidase, $E C$ 3.2.1.55), as shown previously, and by $\beta$-galactosidase (EC 3.2.1.23) (BonhommeFlorentin, $1986 a$ ). The $\beta$-mannosidase (EC 3.2.1.25) activity was weak.

The bacterial fraction also participates mainly in the form of xylanase activity. The contents of the caecum are heterogeneous, as are those of the rumen. They include a complex solid mass of digesta and a liquid phase and therefore offer various microenvironments. Observations using the electron microscope (Bonhomme-Florentin, 1985, $1986 \mathrm{~b}$ ) show micro-organisms attached to the plant-cell constituents. In the present study, the hydrolytic activities correspond to those of the micro-organisms in the caecal liquid phase and, probably, as in the rumen (Williams \& Strachan, 1984), the attached microorganisms are even more important in the breakdown of structural polysaccharides. The actual enzyme activities in the caecum are probably higher than the activities observed in the present work.

\section{REFERENCES}

Abou Akkada, A. R., Eadie, J. M. \& Howard, B. H. (1963). Biochemical Journal 89, $268-272$.

Abou Akkada, A. R. \& El Shazly, K. (1965). Journal of Agricultural Science, Cambridge 64, 251-255.

Abou Akkada, A. R. \& Howard, B. H. (1961). Biochemical Journal 78, 512-517.

Bailey, R. W., Clarke, R. T. \& Wright, D. E. (1962). Biochemical Journal 83, 517-523.

Bonhomme-Florentin, A. (1974). Annales des Sciences Naturelles 12, 155-283.

Bonhomme-Florentin, A. (1985). Reproduction, Nutrition Développement 25, 127-139.

Bonhomme-Florentin, A. (1986a). Reproduction, Nutrition Développement 26, 291-292.

Bonhomme-Florentin, A. (1986 b). Japan Journal of Veterinary Science 48 (2), 313-322.

Clarke, R. T. (1977). In Microbiology of the Gut, pp. 251-275. [R. T. Clarke and T. Bauchop, editors]. London: Academic Press.

Dehority, B. A. (1965). Journal of Bacteriology 89, 1515-1520.

Dehority, B. A. (1973). Federation Proceedings 32, 1819-1825.

Grenet, E., Martin-Rosset, W. \& Chenost, M. (1984). Canadian Journal of Animal Science 64, 345-346.

Harbers, L. H., McNally, L. K. \& Smith, W. H. (1981). Journal of Animal Science 53, 1671-1676.

Hess, K. \& Philipoff, W. (1937). Berichte der Deutschen chemischen Gessellschaft 70, 639-659.

Hintz, H. F. (1969). Veterinarian 6, 45-50.

Hungate, R. E. (1942). Biological Bulletin 83, 303-319.

Lowry, O. H., Rosebrough, N. J., Farr, A. L. \& Randall, R. J. (1951). Journal of Biological Chemistry 193, 265-275.

Macllvaine, T. C. (1921). Journal of Biological Chemistry 49, 183-188.

Mah, R. A. \& Hungate, R. E. (1965). Journal of Protozoology 12, 131-136.

Nelson, N. (1944). Journal of Biological Chemistry 153, 375-380.

Peltonen, T., Kossila, V., Syrjala, L. \& Immonen, I. (1978). Annales Agriculturae Fenniae 17, $109-114$.

Prins, R. A. (1977). In Microbial Ecology of the Gut, pp. 73-183 [R. T. Clarke and T. Bauchop, editors]. London: Academic Press.

Trevelyan, W. E., Procter, D. P. \& Harrison, J. S. (1950). Nature 166, 444-445.

Williams, A. G. \& Strachan, N. H. (1984). Current Microbiology 10, 215-220.

Wright, D. E. (1960). Archives 'of Biochemistry and Biophysics 86, 251-254.

Wright, D. E. (1961). New Zealand Journal of Agricultural Research 4, 203-215. 